
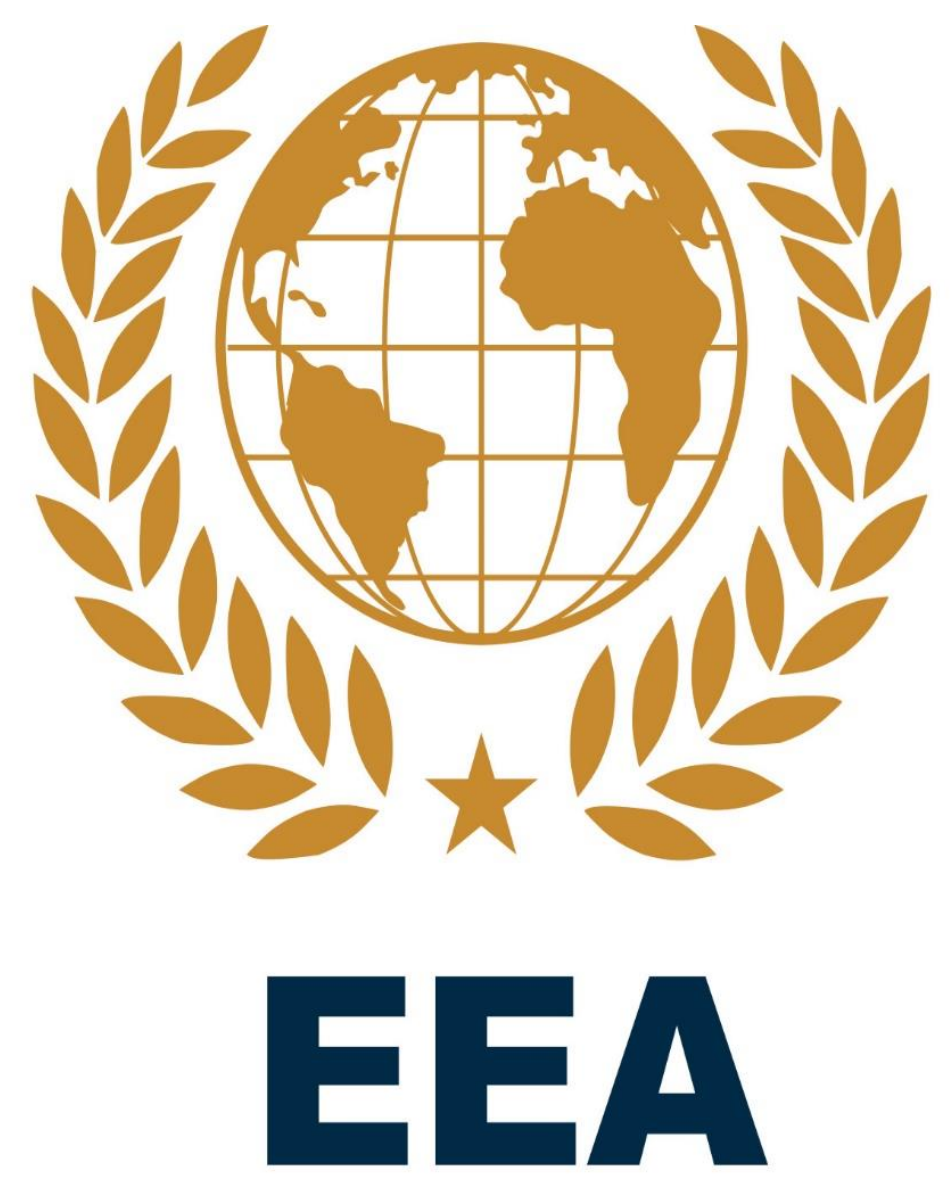

East European Affairs

\author{
3 \\ 2020
}


DOI: 10.47669/EEA-3-2020

\title{
Belarus in the Wake of a Revolution: Domestic and International Factors
}

\author{
Aram TERZYAN*
}

\begin{abstract}
This paper explores the political landscape of Belarus in the aftermath of the 2020 presidential elections, with a focus on both domestic and international factors behind the ongoing crisis. Lukashenko's regime has a long record of sustaining its power by preserving elite unity, controlling elections, and/or using force against opponents. Therefore, massive fraud characterizing the 2020 presidential elections and brutal suppression of peaceful protests in its aftermath came as no surprise. Against this backdrop, the anti-government protests following the presidential elections raised a series of unanswered questions regarding both their domestic and foreign policy implications. The biggest question is whether the Belarusian civil society and opposition will prove powerful enough to overcome state repression and change the status quo in Europe's "last dictatorship". Worries remain about the Belarusian opposition's emphasis on foreign policy continuity, meaning that Belarus is bound to remain in the orbit of the Russian authoritarian influence. The total fiasco of post-Velvet Revolution Armenian government both in terms of domestic and foreign policies, among others, further reveals the excruciating difficulties of a democratic statebuilding within the Russia-led socio-political order.
\end{abstract}

Keywords: Belarus; Russia; Lukashenko's Regime; Democratic Opposition; Post-Soviet Revolutions.

\section{Introduction}

The 2020 post - election upheaval in Belarus, along with the 2018 "Velvet Revolution" in Armenia have renewed scholarly interest in the challenges and opportunities of regime change in Russia's sphere of interest.

Before the Armenian revolution, a series of popular protests, which later became known as 'color revolutions', had led to non-violent toppling of the incumbent authoritarian or/and semi-authoritarian regimes in Georgia, Kyrgyzstan and Ukraine from 2003 to 2005.

There is a lot of scholarship on the political and socioeconomic rationale behind postSoviet revolutions. Given their 'anti-postSoviet' nature, there has been a tendency to regard 'color revolutions' as major international setbacks to Putin's Russia (Finkel and Brudny, 2012). According to widely held beliefs, the 'color revolutions' in Ukraine, Georgia and Kyrgyzstan sought to purge the Newly Independent States' ruling elites and political-

\footnotetext{
* Aram Terzyan, PhD is research director of Los Angeles-based Center for East European and Russian Studies of Eurasia Institutes. Email: a.terzyan@eurasiainstitutes.org .
} 
Belarus in the Wake of a Revolution: Domestic and International Factors

economic systems of residual 'Sovietism' (Nikitin, 2007). In response to "democratic diffusion," Russia resorted to "authoritarian resistance," including a political, administrative, and intellectual assault on the opposition and Western ideas of democracy promotion, integral part of which was the attempt to delegitimize the idea of liberal democracy itself (Ambrosio, 2007; Finkel and Brudny, 2012). Meanwhile, Russia's "indifference" to the 2018 "Velvet Revolution" in Armenia suggests that the latter constitutes an exception to these mainstream explanations. Arguably, in contrast to neighboring Georgia, the post-revolution Armenia's political leadership, has committed itself to further deepening ties with Russia, with no indication of pulling the country out of the Russian influence. Similarly, while it has not been uncommon for the Kremlin propaganda to attribute the Belarusian uprising to "Western intrusion" in the Russian sphere of influence, the Belarusian opposition has not raised the issue of revising relations with Russia. A question arises as to whether a genuine regime change is possible in Russia's sphere of influence.

While the 2018 "Velvet Revolution" in Armenia seemed to defy the Russian "counterrevolution' policy, its disappointing outcomes prompt us to conclude that there was barely a real revolution. Nevertheless, successful, mass-based opposition to a ruling elite tends to serve as an example to discontented elements in other countries. The question as to whether Alexander Lukashenko's authoritarian regime in Belarus is resilient enough to shield itself from the diffusion effects of the 2018 "Velvet Revolution" in Armenia, provokes an inquiry into core domestic and international factors in the Belarusian upheaval.

In search for a parsimonious contribution to the political science literature on social protest, some works delve into the relationship between election and protests and thus apply the collective action framework to 'color revolutions. This approach posits that "electoral fraud can be a remarkably useful tool for solving the collective action problems faced by citizens in countries where governments are not appropriately restrained by the populace" (Tucker, 2007).

Admittedly, the above-mentioned revolutions were significantly fueled by the attempts of authoritarian leaders to sustain the long-term stability of their authoritarian regimes through electoral fraud and consolidation of autocratic control over society.

Alexander Lukashenko's authoritarian regime, established in 1994 and consolidated over a long period of time, seemed to be durable and resistant to change, since decades of continuous repressions pushed the opposition to the margin and stagnated the civil society. 
Lukashenko has invariably tightened his grip on Belarus, not least through restricting political freedoms and civil liberties. Against this backdrop, the 2020 post-election unrest, including the unprecedented wave of protests that was met with massive state repression seemed to challenge the regime's survival. According to widely held beliefs, had the presidential elections been free and fair, Svetlana Tikhanovskaya, former English teacher without any prior political experience would have been elected as President (Kolarzik and Terzyan, 2020). As a presidential candidate Tikhanovskaya mobilized a wide spectrum of the society, serving as the collective symbol of the Belarusian opposition (Specia, 2020).

Perplexingly, both the opposition and the incumbent authorities claim victory. The opposition asserts that in some polling stations Tikhanovskaya won over 70 percent of the vote, contrary to officially announced figures (BBC, 2020a). Conversely, Lukashenko was declared the winner, with 80 percent of the vote and even received congratulations from his foreign counterparts (Deutsche Welle, 2020). While striving to stay in power, Lukashenko's regime seems to suffer from its diminishing ability to coerce the opposition and suppress the civil society.

Clearly, Lukashenko's legitimacy has been eroding over the past decades, fueled by economic and political discontent (Wilson, 2016). Nevertheless, Tikhanovskaya's claims of victory are unsupported by substantial evidence. Backed by a non-institutionalized political opposition, she does not seem to serve as a credible political alternative to Lukashenko (DGAP, 2020). As a result, Belarus has appeared in a situation, where the stances of external actors may play a critical role in determining the winner and resolving the ongoing political crisis.

Given all these, this paper aims at answering the following research questions.

To what extent is the Belarusian opposition institutionalized to serve as a viable and credible political alternative to the incumbent regime?

What is the main geopolitical rationale behind the Belarusian crisis and what are the core interests of the international actors?

The paper will proceed as follows. It starts with a brief introduction to the hallmark of political opposition in Belarus. Next, geopolitical aspects and the interests of external powers will be elucidated. The conclusions summarize the main findings. 
Belarus in the Wake of a Revolution: Domestic and International Factors

\section{Domestic factors: A glance at Belarusian opposition}

There has been a long-standing tendency for post-Soviet governments to downgrade the importance of the political opposition, while failing to accept the idea of opposition as a normal feature of government.

Evidently, opposition plays a crucial role both in democratic and non-democratic regimes. Arguably, in authoritarian regimes the opposition is tasked with a difficult task: to remove the incumbent authoritarian regime and to embark on democratic state-building. Since for the most part this task tends to remain unfulfilled, opposition parties are often deemed to be unsuccessful (Bedford and Vinatier, 2018).

The terms of pre-emptive democracy (2005) and preemptive authoritarianism (2010) have been coined by Silitski to describe the main characteristics of the authoritarian regime in Belarus. As aptly noted by the author, authoritarian regimes survive "not just by sporadic reactions to already existing political and social challenges, but by pre-emptive attacks that eliminate threats before they arise" (Silitski, 2010 p. 342).

There is a whole panoply of preemptive measures at the authorities' disposal, including pressure on civil society, interventions in independent electoral monitoring, promotion of pro-government civil society groups, and even violent assaults on opposition activists (Silitski, 2010).

The strategy of preemption endows the incumbent regimes with competitive advantages, while exacerbating the uneven playfield between government and society. This is hailed as 'hyper-incumbent advantage' by Susan Stewart, Margarete Klein, and Andrea Schmitz (2012).

Besides giving huge competitive advantages, preemption has both psychological and political implications for political opposition. As noted by Silitski (2005) "such systematized repression instils in them a sense of hopelessness and imposes the perception that political change is far beyond reach" (Silitski, 2005, p. 84).

The Belarusian authorities have had a strong tendency of repressing the representatives of opposition after parliamentary and presidential elections. Research shows evidence of repression during the post-election periods, while the arrest or exile of opposition leaders remains the major factor fragmenting the opposition (Konstantin, 2015).

The Belarusian authorities successfully dissipated the threats of the imminent public protests in 2006 and 2010. In 2006, the authorities created artificial barriers for the opposition 
candidates to campaign, through harassing and detaining campaign members. Media coverage was biased, with little to no chances for having the opposition voices heard. Furthermore, the freedoms of expression, association and assembly would remain severely limited (OSCE 2006). Even though there was an improvement in the 2010 presidential elections compared to the previous ones, there was still "a lack of a level playing field between the incumbent and the other nine candidates, and was marked by instances of pressure, harassment and misuse of administrative resources to promote the incumbent" (OSCE, 2010, p. 2)

Against this backdrop, the 2020 presidential elections constituted an exception. On July 15, 2020, the Director of the OSCE Office for Democratic Institutions and Human Rights, that regularly monitors the process of elections in the region, stated that the OSCE group would not implement a monitoring mission in the upcoming presidential elections, since the Foreign ministry of Belarus failed to send them an invitation in a timely manner (OSCE 2020). The authorities would routinely repress journalists and critics during the pre-election period, thus violating their freedom of expression and assembly. It has not been uncommon for journalists to be detained and fined for the mere reason of covering public gatherings (HRW, 2020).

The presidential candidates received their share of restrictions. Namely, Viktor Babaryko, the main rival to President Lukashenko, was detained on suspicion of financial crimes amid increased harassment of opposition figures. After being released, his presidential candidacy was rejected by the Belarusian central electoral commission (Al Jazeera, 2020). Moreover, the Belarusian central electoral commission refused to register him as a candidate for the country's presidential election. The commission also rejected the candidacy of Valery Tsepkalo- another popular opposition figure and a former ambassador to Washington, over a lack of valid signatures (Al Jazeera, 2020). Overall, through May to July, at least 1100 people were arrested for gathering peacefully on issues related to the election. Nearly 200 people were detained for up to 15 days, with some of them more than once. Over 300 people were fined (HRW, 2020)

Ironically, the authorities allowed Tikhanovskaya to register her candidacy, with the anticipation that she would not be able to consolidate the opposition. Notably, she took up the presidential bid only after her husband, popular vlogger Sergei Tikhanovsky, was arrested two days after announcing he planned to run for president (Hart, 2020). 
Belarus in the Wake of a Revolution: Domestic and International Factors

In the light of such repressive measures, opposition parties had little chance to fulfill their agendas. As argued by Stepan (1997) the main goal of the opposition parties in authoritarian regimes is not ousting the incumbent regime, but the incremental process of "authoritarian erosion" (Stepan, 1997, p. 662). The opposition parties contribute to this process "through staying in, or coming into, existence; resisting integration into the regime; guarding zones of autonomy against it; disputing its legitimacy; raising the costs of nondemocratic rule; and creating a credible democratic alternative" (Bedford amd Vinatier, 2018).

In effect, the Belarusian authorities stop at nothing to suppress anti-government protests, not least through using police crackdown against peaceful protesters. Clearly, the repressive measures taken by Lukashenko's regime aim at sustaining its steady survival, while dissipating every threat posed to its rule. Meanwhile, the lack of a well-institutionalized opposition and a vibrant civil society is favorable to Lukashenko, in terms of sustaining his authoritarian rule.

\section{International factors: Explaining the geopolitical rationale}

Situated in the European Union - Russia contested neighborhood, the ongoing crisis in Belarus was bound to attract the regional powers' attention, along with their dissimilar visions of its resolution (Lanteigne, 2020).

Interestingly, despite the scale of the Belarusian crisis, the opposition tends to trace it to domestic, rather than to international factors and thus downplays the geopolitical rationale behind the turbulence. Sviatlana Tsikhanouskaya, the leader of the opposition, notes that "it is neither an anti-Russian nor a pro-Russian revolution. It is neither anti-EU nor pro-EU. It is a democratic revolution" (Dickinson, 2020). Other opposition figures, such as Valery Tsepkalo, shared the same view, contending that they seek free and fair elections, rather than distancing Belarus from Russia (RT, 2020).

Apparently, opposition representatives attempt to downplay the geopolitical aspect of the elections, while emphasizing their agenda of democratic reforms as the main objective.

Against this background, the president of Belarus has attempted to associate the protests with geopolitics. More specifically, Lukashenko feeds the narrative that protesters are backed by the European Union and the USA. He went so far as to contend that there is a special center staging their activities (TASS, 2020). 
Following the gathering of around 200,000 protesters in Minsk, the Coordination Council was established to solve the power crisis, through ensuring and facilitating smooth power transition. The Council claimed to be complying with the provisions of Belarusian Constitution and aimed at preserving the sovereignty and independence of the Republic of Belarus (Coordination Council, 2020). Lukashenko claimed that this "anti- Russian" council was created to illegally seize power. This statement was followed by the detention of all Presidium members of the council, except Nobel Prize Laureate Sviatlana Alexievich (Wesolowsky, 2020).

Unlike other revolutions in post-Soviet space, not only does not the opposition raise the issue of redefining relations with Russia, but also calls on Russia for serving as an arbitrator in the process of power transition. Meanwhile, the European Union denounced the repressions, stressing the necessity of broader national dialogue, which would ultimately satisfy all the parties concerned (European Council, 2020a). While the European Union does not recognize Lukashenko as the elected president, the Kremlin regards Lukashenko as the legitimately elected leader. Moreover, not only did the Russian President Putin congratulate Lukashenko on his reelection, but also supported Lukashenko's proposal of a constitutional reform as a way-out of the crisis, while granting a $\$ 1.5$ billion loan to Belarus as a show of support for Lukashenko (Walker, 2020).

Russia's authoritarian support comes as no surprise. Under the Lukashenko's regime, Belarus has become linked with Russia through a multitude of bilateral treaties and agreements covering virtually all areas of inter-state action. As a result, Russia's relationship with Belarus is closer than that of any other former USSR country. Ambrosio (2006), notes that the situation in Belarus is such that the external factors that have proved to promote democratization have been weakened or undermined by its relationship with Russia in general, and by the proposed Russia-Belarus union in particular (Ambrosio, 2006).

Russian leaders, including Putin, have consistently legitimized Lukashenko's rule both diplomatically and politically, not least through defending Belarus's unfair and unfree elections. In the economic realm, Russia-Belarus trade and Russian subsidies shield Belarus from any possible trade sanctions from Western Europe, thus sustaining the regime's unreformed economic system (Ambrosio, 2006).

Of all Eastern Partnership countries, Belarus is most vulnerable to the Russian influence, with the two countries forming a union state being members of the same defense and economic communities. 
Belarus in the Wake of a Revolution: Domestic and International Factors

Nevertheless, the bilateral relations have not been devoid of tensions. The recent ones included Lukashenko's resistance to economic rapprochement under the terms of the 1999 'Union State' agreement, differences on oil subsidies, along with Lukashenko's attempts at strengthening country's diplomatic ties with the United States and China (Shraibman, 2020). Such steps come down to the Belarusian leadership's plans on diminishing dependence on Russia and seeking a geo-political balance rather than on pulling the country out of the Russian orbit of influence (Astapenia and Balkunets, 2016). Meanwhile, such bold strides tend to run into Russian resistance. This partially explains Russia's tardiness in terms of its reaction to the Belarusian turmoil, despite the new leadership's possible moves towards the West. It is in this context that the protestors ardently strive to dissipate the Kremlin's concerns, by emphasizing the domestic nature of the 'revolution' aimed at fulfilling the agenda of economic and political reforms. The National Coordination Council has confirmed their plans on maintaining close relations with Russia in strict compliance with 'Union State' agreement. Moreover, Tikhanovskaya repeatedly stresses that external players should not interfere in Belarusian domestic affairs (Tavanier, 2020).

The emphasis on continuity in foreign policy is consistent the Armenian revolution leader Nikol Pashinyan's leader. In contrast to their Georgian and Ukrainian counterparts Micheil Saakashvili's and Petro Poroshenko's emphasis on escaping post-Soviet geopolitical space and gaining centrality in the EU-driven socio-political order, the Belarusian opposition does not appear to pursue a 'game changing' agenda (Terzyan, 2020).

Meanwhile, the Kremlin's propaganda tends to overemphasize the geopolitical rationale behind the Belarusian upheaval. The latter is portrayed as a 'Western intrusion' in the sphere of its influence aimed at diminishing the Russian influence in the post-soviet region (Fischer and Sahm, 2020).

Such claims are not novel. Long before the Belarusian events, the Kremlin propaganda would portray "Electric Yerevan" - mass protests over electricity price hikes of Russiandominated Electric Network of Armenia in 2015, as a "Western conspiracy" against Russia. It would feed the narrative that in line with Georgia and Ukraine, the unrests in Armenia might have been incited by the United States to pull the country out of the Russian influence. Namely, Igor Morozov, a Russian Parliament Member from the Federation Council's International Relations Committee, linked Yerevan protests to the pro-European demonstrations in Ukraine that eventually swelled into a revolution leading to the current 
crisis (The Guardian, 2015). "The US Embassy in Armenia is actively involved in the current events in Yerevan...Armenia is now close to a coup d'état with use of firearms" (The Guardian, 2015).

As noted earlier, this line of thinking comes down to the widespread treatment of 'color revolutions' in Georgia, Ukraine and Kyrgyzstan as 'anti-Post Soviet' that sought to purge the Newly Independent States' ruling elites and political-economic systems of residual 'Sovietism' (Nikitin, 2007).

Against this backdrop, the EU has consistently reassured that the West has no design on 'staging' a 'color revolution' in the region. The EU stated outright that the presidential elections were not free and fair, fraught with severe human rights violations. The EU was also resorted to imposing new sanctions on Belarus, confined to asset freeze and travel ban. Those are mostly targeted sanctions on 40 individuals. On November 6, 15 members of the Belarusian authorities, including Alexander Lukashenko were added to this list (European Council, 2020b).

In contrast to the EU's relatively active engagement in conflict the US has not demonstrated any desire of intervention or mediation. Rather, the Washington has confirmed its commitment to supporting Belarus' sovereignty and territorial integrity, while limiting itself to pinpointing the 'serious flaws' in the elections (US Department of State, 2020). Such statements run contrary to Putin's and Lukashenko's penchants for denouncing the USA's destabilizing interferences in domestic affairs of Belarus with the view to fomenting unrest and staging a revolution (CGTN, 2020; Balmforth, 2020).

As for China, its geopolitical interests in Belarus are conditioned by the implementation of the Belt and Road Initiative (BRI) partnerships. However, Beijing proved quick to follow the developments unfolding in Belarus, and slow to react to them. Rather, China congratulated Lukashenko on his reelection while emphasizing its support for 'Belarusian people's choice of development path', and inadmissibility of any foreign intervention (Lanteigne, 2020).

Overall, unlike the diverging visions of the major power centers, there seems to be a broad consensus across the Belarusian society on the necessity of changing the status quo and putting an end to Lukashenko's authoritarian rule. Whether or not the Belarusian civil society will be able to overthrow its previously unchallenged leader is yet to be seen. Worries remain about the Belarusian opposition's emphasis on foreign policy continuity, meaning that Belarus is bound to remain in the orbit of the Russian authoritarian influence. 
Belarus in the Wake of a Revolution: Domestic and International Factors

\section{Conclusions}

Based on the previous discussion, there are a few main concluding observations to make regarding the political landscape of Belarus in the wake of a revolution.

Lukashenko's regime has a long record of sustaining its power by preserving elite unity, controlling elections, and/or using force against opponents. Therefore, massive fraud characterizing the 2020 presidential elections and brutal suppression of peaceful protests in its aftermath came as no surprise.

The electoral history of Belarus suggests that elections under Lukashenko's rule have been pre-determined 'contests' under the ruling elites' full control, rather than major struggles between opposition and the regime. Against this backdrop, the anti-government protests following the 2020 presidential elections show that the Belarusian opposition and civil society have the potential to challenge the status quo meticulously preserved by Lukashenko. Essentially, successful, mass-based opposition to the ruling elite, that led to the 2018 "Velvet Revolution" in Armenia served as an example to discontented elements in Belarus. To shield itself from the diffusion effects of the Armenian revolution, the Belarusian regime has reinforced its repressive toolkit - deployed to suppress the civil society, coerce the opposition, and prevent the latter from turning into a viable and credible alternative to the incumbent authority. Nevertheless, the scale of anti-government protests is a testament to Lukashenko's diminishing ability to sustain his regime's stability by traditional coercive measures. The question remains as to whether the civic activism will prove powerful enough to overcome the state repression and change the status quo in Europe's "last dictatorship." Worries remain about the Belarusian opposition's emphasis on foreign policy continuity, meaning that Belarus is bound to stay in the orbit of the Russian authoritarian influence.

In contrast to their Georgian and Ukrainian counterparts Micheil Saakashvili's and Petro Poroshenko's emphasis on escaping post-Soviet geopolitical space and gaining centrality in the EU-driven socio-political order, the Belarusian opposition does not appear to pursue a 'game changing' agenda.

Conventional wisdom suggests that the chances of democratization across a vast swath of Eurasia seem slimmer now, than ever before in the face of Russian President Vladimir Putin's crackdown on liberal-democratic forces at home and abroad. Indeed, the total fiasco of post-Velvet Revolution Armenian government both in terms of domestic and foreign policies, among others, further reveals the excruciating difficulties of a democratic state- 
building in the orbit of the Russian influence. Whether or not a possible domestic change in Belarus will be more successful is yet to be seen. At this point there is little ground for optimism amid the country's unshakeable allegiance to the Kremlin, along with the difficulties of diminishing economic and political dependence on Russia.

\section{References}

Al Jazeera (2020). Belarus Election Commission Refuses to Register President's Rival. Retrieved November 20, 2020 from https:/www.aljazeera.com/news/2020/7/14/belaruselection-commission-refuses-to-register-presidents-rival .

Ambrosio, T. (2007). Insulating Russia from a Colour Revolution: How the Kremlin Resists Regional Democratic Trends. Democratisation, 14(2), pp. 232-252.

Ambrosio, T. (2006). The Political Success of Russia-Belarus Relations: Insulating Minsk from a Color Revolution. Retrieved November 21, 2020 from https://demokratizatsiya.pub/archives/14_3_9162J67W06523546.pdf.

Astapenia, R., Balkunets, D. (2016). Belarus-Russia Relations after the Ukraine $\begin{array}{lllll}\text { Conflict. } & \text { Retrieved } & \text { November } & 21, & 2020\end{array}$ http://belaruspolicy.com/sites/default/files/articles/21.09.2016/belarus-russiarelations_en.pdf.

Balmforth, T. (2020). Russia Accuses U.S. of Promoting Revolution in Belarus, Toughens Stance. Retrieved December 20, 2020 from https://www.reuters.com/article/usbelarus-election-idUSKBN2672NC.

BBC (2020a). Belarus Election: Clashes after Poll Predicts Lukashenko Re-election. Retrieved November 21, 2020 from https://www.bbc.com/news/world-europe-53717834.

BBC (2020b). Belarus Election: 'Not one Life is Worth what is Happening Now'. Retrieved December 20, 2020 from https://www.bbc.com/news/av/world-europe-53737449.

Bedford, S. and Vinatier, L. (2018). Resisting the Irresistible: 'Failed Opposition' in Azerbaijan and Belarus Revisited. Government and Opposition, 54, pp. 1-29.

CGTN (2020). Belarus Leader Blames U.S. Involvement, Vows to End Protests. Retrieved November 21, 2020 from https://news.cgtn.com/news/2020-08-22/Belarusleaders-blames-U-S-s-involvement-vows-to-end-protests-T9IFrhv5AY/index.html.

Coordination Council (2020). Coordination Council. Retrieved November 21, 2020 from https://rada.vision/en .

Deutsche Welle (2020). Belarus Election: Lukashenko Wins Another term, Election Commission Says. Retrieved December 14, 2020 from https://www.dw.com/en/alexanderlukashenko-wins-belarus-election/a-54506718.

Dickinson, P. (2020). Putin's Fear of Democracy is Fueling the Crisis in Belarus.

$\begin{array}{llll}\text { Retrieved November } & 21, & \text { from }\end{array}$
https://www.atlanticcouncil.org/blogs/ukrainealert/putins-fear-of-democracy-is-fueling-thecrisis-in-belarus/.

European Council (2020a). Belarus: Declaration by the High Representative on behalf of the European Union on the escalation of violence and intimidation against members of the Coordination Council. Retrieved November 21, 2020, from 
Belarus in the Wake of a Revolution: Domestic and International Factors

https://www.consilium.europa.eu/en/press/press-releases/2020/09/11/belarus-declarationby-the-high-representative-on-behalf-of-the-european-union-on-the-escalation-of-violenceand-intimidation-against-members-of-the-coordination-council/.

European Council (2020b). Belarus: EU imposes sanctions for repression and election falsification. Retrieved November 24 from https://www.consilium.europa.eu/en/press/pressreleases/2020/10/02/belarus-eu-imposes-sanctions-for-repression-and-election-

falsification/.

Finkel, E. and Brudny, Y. M. (2012). Russia and the Colour Revolutions. Democratization, 19(1), pp. 15-36.

Fischer, S. and Sahm, A. (2020). Belarus: Is There a Way Out of the Crisis? Retrieved November 21, 2020 from https://www.swp-berlin.org/en/publication/belarus-is-there-a-wayout-of-the-crisis/.

Hart, E. (2020). 'This is a Turning Point in Belarusian History' Opposition Leader Svetlana Tikhanovskaya on how her Presidential Campaign is Taking on Lukashenko. Retrieved November 21, 2020 from https://meduza.io/en/feature/2020/07/27/this-is-aturning-point-in-belarusian-history.

HRW (2020). Belarus: Crackdown on Political Activists, Journalists. Retrieved November 21, 2020 from https://www.hrw.org/news/2020/07/30/belarus-crackdownpolitical-activists-journalists.

Kolarzik and Terzyan (2020). The State of Human Rights and Political Freedoms in Belarus: Was the Crisis Inevitable? Post-Soviet Politics Research Papers, Number 4, pp. 215 .

Konstantin, A. (2015). The Election Trap: The Cycle of Post-Electoral Repression and Opposition Fragmentation in Lukashenko's Belarus. Democratization, 22(6), 1030-1053, DOI: 10.1080/13510347.2014.899585.

Lanteigne, M. (2020). Geopolitics Returns to Belarus. Retrieved November 21, 2020 from https://www.eesc.lt/en/2020/11/14/marc-lanteigne-geopolitics-returns-to-belarus/.

Nikitin, A. (2007). The End of the 'Post-Soviet Space': The Changing Geopolitical Orientations of the Newly Independent States. Retrieved November 20, 2020 from https://www.chathamhouse.org/sites/default/files/public/Research/Russia\%20and\%20Euras ia/bpnis0207.pdf .

OSCE (2006). Republic of Belarus. Presidential Elections 19 March 2006. Retrieved November 19, 2020 from https://www.osce.org/files/f/documents/4/c/19395.pdf.

OSCE (2010). Republic of Belarus. Presidential Elections 19 December $\begin{array}{lllll}2010 . & \text { Retrieved } & \text { November } & 21, & 2020\end{array}$ https://www.osce.org/files/f/documents/6/4/75713.pdf.

OSCE (2020). ODIHR will not Deploy Election Observation Mission to Belarus due to Lack of Invitation. Retrieved from https://www.osce.org/odihr/elections/457309 .

RT (2020). Belarusians Want Democratic Country and 'excellent relations' with Russia - Blocked Opposition Presidential Candidate Tsepkalo. Retrieved November 21, 2020 from https://www.rt.com/russia/499969-belarusians-want-democracy-relationship-russia/. 
Shraibman, A. (2020). Mercenaries' Arrests Deepen Minsk-Moscow Rift. Retrieved November 20, 2020 from https://carnegie.ru/commentary/82417.

Silitski, V. (2005). 'Pre-empting Democracy: The Case of Belarus'. Journal of Democracy, 16(4), pp. 83-97.

Silitski, V. (2010). Survival of the Fittest: Domestic and International Dimensions of the Authoritarian Reaction in the Former Soviet Union Following the Colored Revolutions. Communist and Post-Communist Studies, 43(4), pp. 339-50.

Specia, M. (2020). Who Is Svetlana Tikhanovskaya, Belarus's Unlikely Opposition Leader? $\quad$ Retrieved $\quad$ November $\quad 21, \quad 2020$ from https://www.nytimes.com/2020/08/13/world/europe/belarus-opposition-svetlanatikhanovskaya.html.

Stewart, S., Klein, M. and Schmitz, A. (2012). Presidents, Oligarchs and Bureaucrats: Forms of Rule in the Post-Soviet Space. Burlington, VT: Ashgate.

TASS (2020). Lukashenko Accuses US and Europe of Orchestrating Belarusian Protests. Retrieved November 21, 2020 from https://tass.com/world/1192317.

Tavanier, R. (2020). Belarusian Protests: Russia's Reluctance. Retrieved November 21, 2020 from https://globalriskinsights.com/2020/09/belarusian-protests-russias-reluctance/.

Terzyan, A. (2020). Post-Soviet Revolutions and Post-Revolution Discourses: Explaining the Construction of Political Identities in Post-Rose Revolution Georgia and PostVelvet Revolution Armenia. Slovenská politologická revue, 20(1), pp. 138-163.

Tucker, J. A. (2007). Enough! Electoral Fraud, Collective Action Problems, and PostCommunist Colored Revolutions. Perspectives on Politics, 5(3), pp. 535-551.

US Department of State (2020). Supporting the Aspirations of the Belarusian People United States Department of State. Retrieved November 21, 2020 from https://www.state.gov/supporting-the-aspirations-of-the-belarusian-people/.

Walker, S. (2020). Russia to Lend Belarus \$1.5bn as Lukashenko Tells Putin 'a Friend is in Trouble'. Retrieved November 24, 2020 from https://www.theguardian.com/world/2020/sep/14/alexander-lukashenko-vladimir-putinsochi-belarus-russia.

Wesolowsky, T. (2020). What Exactly is the Coordination Council and What are its Plans to Oust Belarus's Leader? Retrieved November 21, 2020 from https://www.rferl.org/a/30802198.html .

Wilson, A. (2016). Belarus: From a Social Contract to a Security Contract? The Journal of Belarusian Studies, 8(1), pp. 78-91.

Wilson, A. (2020). Elections 2020 through the Prism of Silitski's Ideas. Retrieved November 24, 2020 from https://belinstitute.com/en/article/elections-2020-through-prismsilitskis-ideas. 